\title{
KSPM GOES TO KSE AS A CAPITAL MARKET LITERATION LEARNING MEDIA
}

\author{
Tine Badriatin ${ }^{1}$, Astri Handari ${ }^{2}$, Linda Septiana ${ }^{3}$, Rois Bahri ${ }^{4}$ \\ 1,2,3,4 Siliwangi University, Tasikmalaya, Indonesia

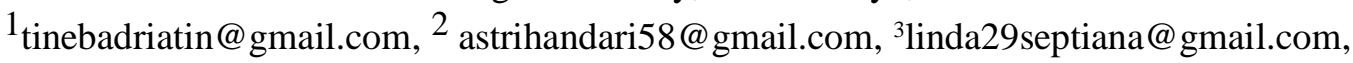 \\ ${ }^{4}$ roisbahri@gmail.com
}

\begin{abstract}
In carrying out its duties and obligations, the KSPM (Capital Market Study Group) Universtas Siliwangi must provide education and outreach to the general public and students of Siliwangi universities in particular. In addition, the KSPM Siliwangi University must also establish cooperative relations with other institutions both at the faculty level in other universities or universities. So as to maximize the performance of Siliwangi University KSPM to be always active and develop with other KSPM circles, in this case the capital market group in Unswagati named KSE (Economic Study Group). The form of this activity is a panel discussion as a means of exchanging information that is educational and literacy to discuss about Capital Market knowledge, the performance of management and as a form of hospitality visits. This comparative study was attended by 14 people from the board of KSPM Siliwangi University by taking the theme let's share, let's study. The target in this activity is the Management of the KSPM Siliwangi University, Tasikmalaya. The results of this program are to increase knowledge and insights that will be applied to the progress of the organization, namely KSPM, especially in capital market education and literacy, in addition to learning the advantages of other KSPM in order to improve work programs for the better.
\end{abstract}

Keywords: KSPM, Capital Market, Literacy

\section{A. Introduction}

The Capital Market Study Group is a vehicle for developing financial interests for students and the general public at Siliwangi University. Activities in the Capital Market Study Group which involve active students of Siliwangi University as administrators of the capital market study group.
There are four functions that are owned by the Siliwangi University KSPM namely IT and analys data functions, social and education, public relations, and events. The management of Siliwangi University KSPM is a student who has been declared to pass through the administrative selection and other requirements that must be 
met so that he becomes the official of the management of KSPM Siliwangi University in 2019.

In carrying out its duties and obligations, the KSPM Universtas Siliwangi must provide education and outreach to the general public and students of Siliwangi universities in particular. In addition, the KSPM Siliwangi University must also establish cooperative relations with other institutions both at the faculty level in other universities or universities. So as to maximize the performance of Siliwangi University KSPM to be always active and develop with other KSPM circles.

The Siliwangi University Capital Market Study Group is also one of the study groups working in the capital market world. The management of Siliwangi University KSPM consists of students who want to deepen their knowledge related to the capital market. In order to increase capital market knowledge in greater depth and realize work programs, KSPM UNSIL will conduct a comparative study to KSPM units on other campuses. In addition to increasing knowledge and ability to invest in the capital market (Badriatin, Tine \& Rinandiyana, Lucky Radi: 2019).

Therefore, the Siliwangi University Capital Market Study Group conducted a comparative study visit to the KSPM Universitas Swadaya Gunung Jati in the Cirebon area. This comparative study provides an opportunity for the KSPM Board of Siliwangi University to establish good relations with the Management of KSPM Swadaya Gunung Jati University in communication. The KSPM on the Unswagati campus is called KSE (Economic Study Group). The comparative study is expected to be able to synergize work programs at KSPM Siliwangi University and be able to share information and education to be able to further develop the Capital Market Study Group. However, the 
target of capital market education and socialization itself is not only aimed at the management of the KSPM itself but also to other academic community members (Badriatin, Tine. Septiana, Linda \& Rinandiyana, Lucky Radi: 2019).

\section{B. Method of Implementation}

The form of this activity is a panel discussion as a means of exchanging information that is educational and literacy to discuss about Capital Market knowledge, the performance of management and as a form of hospitality visits. This comparative study was attended by 14 people from the board of KSPM Siliwangi University by taking the theme let's share, let's study. The target in this activity is the Management of the KSPM Siliwangi University, Tasikmalaya.

$$
\text { According to Usman, }
$$
Mohammad Uzer (2005: 94), the meaning of discussion is an organized communication process involving a group of people in informal face-toface interaction by sharing experiences or information, drawing conclusions, and solutions / problem solving.

While Literacy according to Alberta (2004) is the ability to read and write, increase knowledge and skills, think critically in solving problems, and the ability to communicate effectively that can develop potential and participate in people's lives.

According to previous research results Khotimah, Husnul et al (2015) the existence of socialization and knowledge both partially and simultaneously had a significant effect on investor interest in this matter either KSPM or KSE.

According to the Capital Market Law No. 8 of 1995 concerning the Capital Market defines the capital market as follows: "Activities related to public offering and trading of Securities, Public companies related to the issuance of Securities, and institutions and professions related to 
Securities." The Capital Market is a market for various financial instruments long-term tradable (IDX 2019)

\section{Result and Discussion}

Gunung Jati Swadaya University has an economic community that is the "Economic Study Group" where the activity is divided into two groups namely Tax Center and Investment Gallery. Gunung Jati University Investment Gallery was established in 2013 and every year gets championships from several competitions such as stocklab competitions both provincial and national level. The results of the competition will certainly be a motivation for members to continue their footsteps and develop GIBEI even further. In carrying out its activities, GIBEI and KSE join and collaborate well with each other and do not forget the support of external parties such as Securities and OJK.
1. The organizational structure of GIBEI consists of:

Two lecturers and Management of GIs is assisted by KSE (Economic Study Group) both for GIBEI and Tax Center. 25 students include core staff and divisions. The GIBEI Division is divided into 3 namely: Technical Division, Fundamental Division, and Art Media Division.

As for the implementation, each division does its work so that social media is scheduled for posting. Example 2 days for technical, 3 days fundamentally and every activity is immediately posted and other commemorative days.

In the reorganization activities, GIBEI Gunung Swadaya University undertook several stages:

a. Open Recruitment for 1 month as many as 60 people 2 -month learning (basic capital market and basic taxation)

b. Test written test of learning as many as 40 people 
c. Test presentations of 30 people

d. Interview test for 15 people

e. Placement and division of tasks for new management

f. A maximum of semester 4, which does not become an administrator, becomes a member, and level 4 must retire

g. May not join Ormawa, UKM, or other organizations

h. New KSE members are required to open a stock account

i. Each member of the economic study group is required to master the material both the tax center and the capital market

j. Educating the candidates for management of GIBEI Swadaya Gunung Jati University before conducting the selection, the reorganization committee carries out education to prospective administrators so that if they do not qualify for management, they will still gain capital market knowledge or taxcentre
Finance is also an important thing besides the course of the organization, such as :

a. funding of activities is assisted by 3rd parties (securities or OJK)

b. carry out activities and sell food purchased by management or members

c. KSE management cash Rp.5,000 per week

d. Income from KSE alumni

e. The imposition of fines for the management of late picket 6 . funds for the purchase of company financial statement data for students who are writing their theses on the exchanges included in the KSE and GIBEI operational Gunung Swadaya University Jati Rp. 3000, per data

The legality and bureaucracy at GIBEI Gunung Swadaya University are as follows:

a. form a community and under the auspices of FE

b. There is no AD / ART because KSE Gunung Jati Swadaya University joins the gallery

c. Tax center decree and gallery Decree are different and change according to the dean and lecturer 
name

d. the letter is signed by the gallery president and known by the dean

e. every submission of a proposal involving an independent fund, the dean is only given a notification letter

f. the Management Responsibility Report at the end of the period.

g. there is no submission of proposals and LPJ to anyone, except those who provide funds for the activities of the GIBEI Gunung Swadaya University

h. make integration with activities that really unite and the job desk has to do by the subject of division not by the other

i. GIBEI Gunung Jati Swadaya University must control more so that KSE does not lose its direction in carrying out its activities.

Securities that partnered with GIBEI Gunung Jati Swadaya University such as Sinar Mas's initial partner, Kresna, and currently partnered with MNC Sekuritas. Forms of security support such as Topup vouchers, souvenirs, speakers, certificates and so forth. However, the securities do not stand by on campus so that customers who will open a stock account can be assisted by KSE management who have been licensed. If you want to propose a replacement for securities, you can first look at the Cooperation Agreement (PKS), namely the deadline, rights \& obligations of each party, then submit it to the local campus rector and the Indonesia Stock Exchange.

The work programs of GIBEI Gunung Jati Swadaya University include:

a. Market outlook

b. Time to invest

c. Market updates

d. Capital Market Schools

e. Online trading competition

f. Visit to Issuers

g. Introducing the capital market early on at the high school / vocational level which is conducted every month for students.

h. Learn the capital market for students and the public Capital Market Socialization to the community and school children by holding a stand at the CFD and coming to nearby high school / vocational high school students who will be potential campus students, going to school, school boarding schools, stocklab competitions in each division, 
fundamental and technical studies directly internally or each KSE member.

The customer gained by Gibei for 3 years is approximately 800 customers. Social media is one of the tools used by KSE to introduce its brand to the public both internally and externally on campus. Every day always post the latest info from the capital market or gibei activities so that people know how to do gibei activities and obtain useful information, especially for those who are involved in the capital market world. The posting activity was carried out by several people starting from the section looking for info, making designs, and posting.

Quality improvement and ways to attract new investors:
a. promotion through tangible evidence

b. the role of the lecturer in promoting GIBEI in each class

c. KSE for the daily activities of the Tax Center \& GIBEI so that the gallery is always busy with scheduled training, such as learning corel draw, spss, English, accounting, taxation, technical, fundamental, review of the Tax Law, tax practices etc.

d. Daily presenters or learning for competitions from the related alumni

e. The KSE room is so comfortable with adequate facilities that supports students to study well. Funds needed by KSE for operational activities and competitions are obtained from cash Rp.5,000 per week, selling snacks (honest canteens), from the results of competition winners, donors, alumni, and other supporters.

f. Opening an account by KSE management, sending files once a week

\section{GI \& KSE}

a. Merged due to limited human resources 
b. To make the gallery crowded and belong to each other

c. Any individual competition can be participated by anyone, for the group competition is prioritized from KSE

\section{Socialization to high school}

a. every month 1 school

b. licensing to the provincial Education Office

c. presenters from OJK and securities

d. GI and KSE as the organizer

Post ig feeds every day, always updated about the stock price recommended by $\mathrm{AB}$ analysis report to the group by the head of securities, securities operational salesman, and gallery and then analyzed by KSE then posted

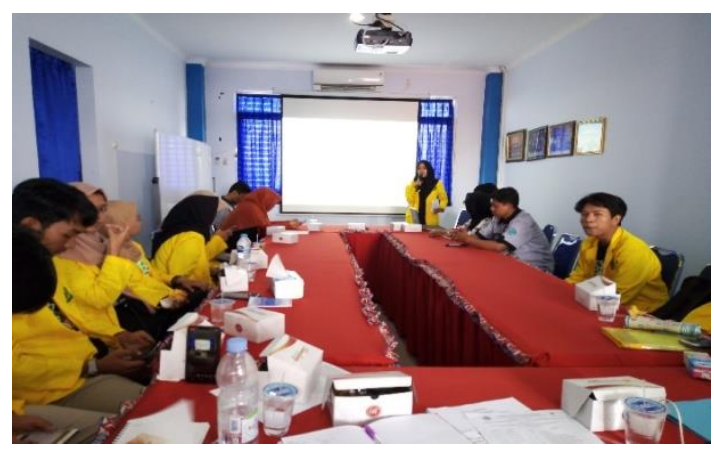

Figure 1. Presentation by the Chairperson of KSPM Siliwangi University

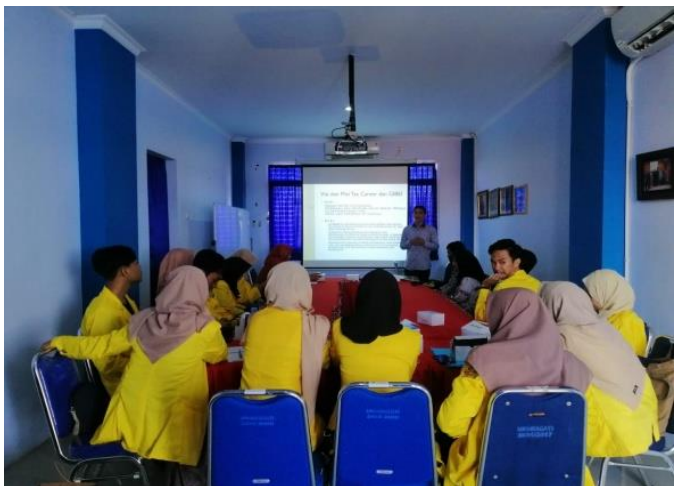

Figure 2. Presentation by Chairperson of KSE GIBEI Swadaya Gunung Jati University

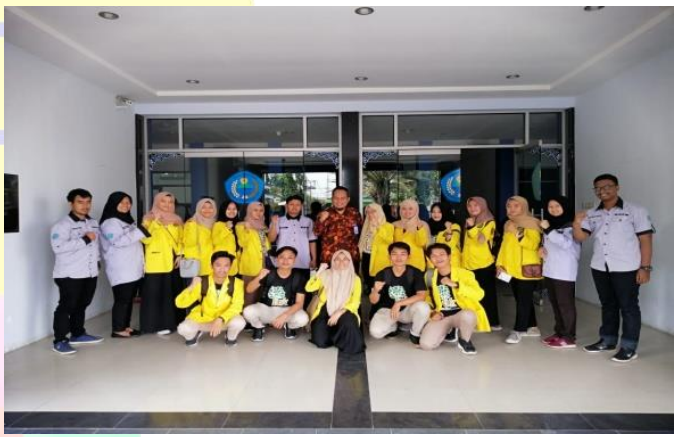

Figure 3. Participants in the discussion of KSPM UNSIL and KSPM

Unswagati

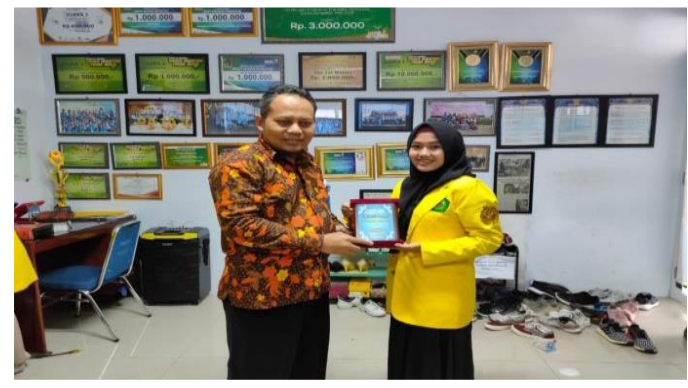

Figure 4. Submission of Souvenirs

\section{Conclusion}

The conclusion from the activities of the KSPM goes to KSE as 
a media for learning capital market literacy is to achieve the objectives of which can be:

1. Increase knowledge of the Management of Siliwangi University KSPM

2. Strengthen friendship ties and improve good relations between the Management Board of Siliwangi University with the Management of KSPM Swadaya University Gunung Jati

3. Creating a means of exchanging information among KSPM

4. Improving the performance of Siliwangi University KSPM Management

\section{REFERENCES}

Alberta, (2004). Focus On Inquiry: a teacher guide to implementing inquiry-based learning. Retrieved from: http://www. learning. gov. ab. ca/k_12 / curriculum bySubject/jocusoninquiry.pdf.

Badriatin, Tine. Septiana, Linda. Rinandiyana, Lucky Radi.
(2019). The KSPM Program Goes to Ormawa for Capital Market Literacy and Education. JCES (Journal of Character Education Society, Vol. 2, No.2, Juli 2019. 28-33.

Badriatin, Tine \& Rinandiyana, Lucky Radi. (2019). New Investor Class Program As A Means ti Increase Capital Market Literation and Inclusion in Faculty of Economic Students of Siliwangi University Through GIBEI-FE UNSILRELI. Prosiding Seminar Nasional \& Call for Paper 2019 Pengabdian Kepada Masyarakat : Pembangunan Ekonomi Berkelanjutan Dalam Revolusi Industri 4.0 Fakultas Ekonomi dan Bisnis Universitas Lampung. Oktober 2019, 254-259.

Hogan, Nicky. (2019). Simple Stories for a SIMPLE INVESTOR Stop being njlimet!'”. Jakarta. PT. Elex Media Komputindo.

IDX. (2019). Pengantar Pasar Modal. Retrieved from https://www.idx.co.id/investor/p engantar-pasar-modal/ Khotimah, Husnul et.al. (2015). Pengaruh Sosialisasi dan Pengetahuan terhadap Minat 
Investor pada Efek Syariah di

Pasar Modal (Survei pada

Nasabah PT. Danareksa

Sekuritas Cabang FE - UI

Depok). Jurnal Politeknik Negeri

Jakarta.

Undang-Undang Pasar Modal No. 8

tahun 1995 tentang Pasar Modal

Uzer Usman, Moh. (2005). Menjadi

Guru Profesional. Bandung:

Remaja Rosdakarya 